\title{
THE INCREASED BODY MASS INDEX EFFECT ON DECLARATIVE MEMORY
}

\author{
WZROST WSKAŹNIKA MASY CIAŁA \\ MOŻE MIEĆ NEGATYWNY WPŁYW NA PAMIĘĆ DEKLARATYWNĄ
}

\footnotetext{
${ }^{1}$ Department of Human Physiology, Nicolaus Copernicus University, Collegium Medicum Bydgoszcz, Poland ${ }^{2}$ Centre for Physical Education and Sport, Nicolaus Copernicus University, Collegium Medicum Bydgoszcz, Poland ${ }^{3}$ Department of Neuroimmunology, Nicolaus Copernicus University, Collegium Medicum Bydgoszcz, Poland
}

\section{S u m m a r y}

Several lines of evidence suggest that being overweight or obese not only impacts the cardiovascular and respiratory systems but also exert a negative effect on the central nervous system. We examined the relationship between body mass index and cognitive performance in three groups of volunteers: obese (17 women; aged $59.88 \pm 4.29$; BMI 34.08 \pm 2.31 ), overweight (35 women; aged $59.70 \pm 4.68$; BMI
$27.87 \pm 1.44$ ), and normal body weight group (18 women; aged $64.5 \pm 4.84$; BMI $23.53 \pm 1.21$ ). To evaluate the cognitive performance in our subjects we used face/name association test. Our data demonstrate that the increased body mass weight may have a negative effect on some cognitive function such as declarative memory.

\section{Streszczenie}

Wyniki dotychczas przeprowadzonych badań wykazały, że rozwój nadwagi oraz otyłości oprócz negatywnego wpływu na funkcjonowanie układu sercowonaczyniowego czy też oddechowego może również prowadzić do powstawania niekorzystnych zmian $\mathrm{w}$ funkcjonowaniu ośrodkowego układu nerwowego. Zbadano zależność pomiędzy wartością wskażnika masy ciała a zdolnościami poznawczymi w trzech grupach wolontariuszy: osób otyłych

Key words: face/name association, memory, body weight, BMI Stowa kluczowe: kojarzenie twarz/imię, pamięć, masa ciała, BMI

\section{INTRODUCTION}

It is well known that the excessive body weight have a negative effect on overall health. Several lines of evidence indicate that increases in body weight may be associated with hypertension, stroke, heart disease, skeletomuscular diseases, urinary incontinence, knee osteoarthritis, respiratory problem and mellitus
(17 kobiet; wiek 59,88 $\pm 4,29$; BMI 34,08 $\pm 2,31$ ) osób z

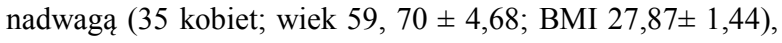
osób z prawidłową masą ciała (18 kobiet; wiek 64,5 $\pm 4,84$; BMI 23,53 $\pm 1,21$ ). Do określenia funkcji poznawczych użyto testu kojarzenia twarz/imię. Otrzymane wyniki wskazują, że wzrost masy ciała może mieć negatywny wpływ na pamięć deklaratywną.

diabetes [1, 2, 3, 4, 5]. Obesity is also described as one of the factors predisposing to development of many types of cancer, for example breast, colon and pancreas [6]. Recent research reports suggest that increased body weight may also be associated with reduced cognitive performance such as learning, memory and executive function $[7,8,9,10,11,12]$. Furthermore, obesity is described as a very important risk factor for 
dementia and neurodegenerative diseases such as Alzheimer's disease [13, 14, 15].

The potential mechanism for the effect of increased body mass on the central nervous system is unclear but a growing body of research suggests that being overweight or obese is related to atrophy of certain areas of the brain. The MRI/CT analysis demonstrated that a higher body mass was associated with lower whole brain volume. Some studies have demonstrated that the structures of the brain that are particularly sensitive to increases in body weight include temporal and frontal lobes, parietal cortex, hippocampus, cerebellum and midbrain. In obese people, reduction in grey matter volume was observed in this areas $[16,17$, 18, 19]. Moreover, experimental studies in animals demonstrated that mechanism of obesity-related cognitive dysfunction may be related to reduced synaptic plasticity in the hippocampus and cerebral cortex [20,21] or increased neuronal apoptosis in the hippocampus and hypothalamus [22]. Currently, it is accepted that potential side-effects include impairment of cerebral metabolism [23], elevated leptin levels [24, $25,26]$, and systemic and central inflammation [27].

\section{MATERIAL AND METHODS}

The study was conducted in accordance with the Declaration of Helsinki for Human Studies. The study protocol was approved by a local Ethics Committee.

Volunteers (70 women, age $60.95 \pm 4.97$ ) were recruited from the local The Third Age University in Bydgoszcz. The volunteers were divided on three groups, differentiated by body mass index (BMI): obese group (17 women; aged $59.88 \pm 4.29$; BMI $34.08 \pm 2.31$ ), overweight group (35 women; aged $59.70 \pm 4.68$; BMI 27.87 \pm 1.44$)$ and normal body weight group (18 women, aged $64.5 \pm 4.84$; BMI 23.53 \pm 1.21 ). Based on medical examination and interviews, the selected women were healthy, and did not suffer from any serious chronic condition, were postmenopausal, and had not underwent hormone replacement therapy.

Body weight status was assessment based on BMI calculated according to the standard formula (weight in kilograms divided by height in square meters). BMI was categorized according to the National Institutes of Health obesity standard: BMI 18.5-24.9 normal weight, BMI 25-29.9 overweigh, BMI 30-34.9 class I obesity [28].
Evaluation of cognitive abilities was measured using a face/name association test. The detailed experimental protocols for these tests were described previously [29]. Shortly, in the acquisition phase of the face/name association test, subjects were exposed to 100 faces associated with a single name on a computer screen. Each face/name pair was presented for 2 seconds. After $10 \mathrm{~min}$ from the end of acquisition phase the retrieval phase began. During this phase test subjects were presented with the same faces as in acquisition phase but each face was associated with two names, one of which was the same name as in acquisition phase. The task of the subject was to indicate the name associated with the face during acquisition phase. No time limitations for retrieval phase were imposed by the protocol. The percent of correctly answered names, and the duration of the retrieval phase were monitored for each subject.

Statistical significance of the differences between the two groups was assessed using two-tailed T-Test. The results are presented as means with standard deviation. $\mathrm{p}<0.05$ was considered statistically significant.

\section{RESULTS}

In the normal body mass group, the mean score of face/name association test was $71.94 \pm 8.93 \%$. In the same test for the overweight and obese group, the scores were $60.44 \pm 8.3 \%$ and $61.00 \pm 11.72$, respectively (Fig. 1a). The scores between overweight and the normal weight group as well as between the obese and the normal weight group were different at statistically significant level, with $\mathrm{p}<0.005$. Statistically significant differences were observed also between the two groups for the duration of the retrieval phase of this test. The normal weight group mean retrieval duration equalled $196.21 \pm 74.56$ seconds and in the overweight group the retrieval duration was $303.29 \pm 122.66$ while the obese group was $307.64 \pm$ 139.97 seconds (Fig. 1b). We observed a positive relationship between BMI and the results face/name association test $(\mathrm{p}<0.005)$ (Fig. 2a, 2b). 

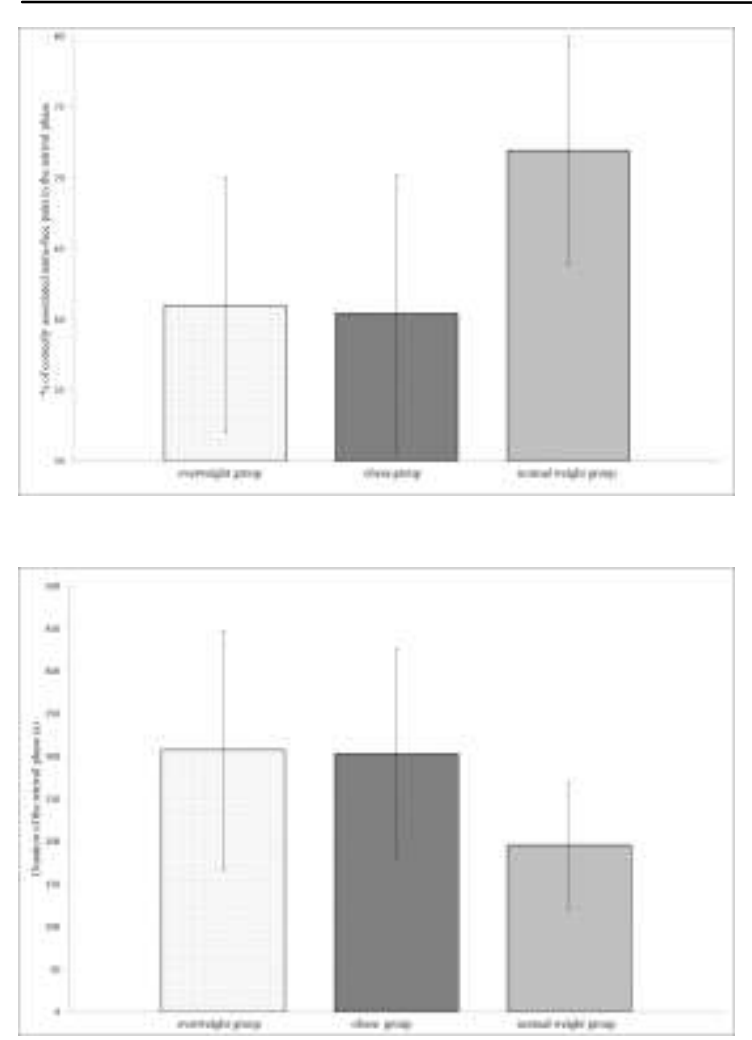

Fig. 1. Face/name association test results in normal, overweight and obese groups. A) The mean values for \% of correctly associated name-face pairs

$\backslash( \pm S D)$, in the retrieval phase. B) The mean values duration of the retrieval phase $( \pm S D)$

Ryc. 1. Wyniki testu kojarzenia twarz/imię $w$ grupie $z$ prawidlowa masa ciala, nadwaga oraz $w$ grupie osób otylych. \% twarzy poprawnie skojarzonych z imieniem $w$ fazie odtwarzania a) średnie wartości uzyskane $w$ poszczególnych b) Czas trwania fazy odtwarzania

\section{DISCUSSION}

In this study we examined the relationship between body mass index and cognitive performance (declarative memory) in elderly, health women. The data presented in this report indicate that there is a dependence between body mass weight and declarative memory. Our studies revealed that persons with a normal body weight scored higher in the face/name test compared with the overweight $(\mathrm{p}<0.005)$ and obese $(\mathrm{p}<0.005)$ subject. Overweight and obese subjects demonstrated lower accuracy in name/face association task and longer times of completion for this test. We demonstrated correlation between Body Mass Index and the results of face/name association test. The increased body mass impacted negatively the percentage of names correctly associated with faces and also resulted in prolongation of the retrieval phase of the test $(\mathrm{p}<0.005)$.

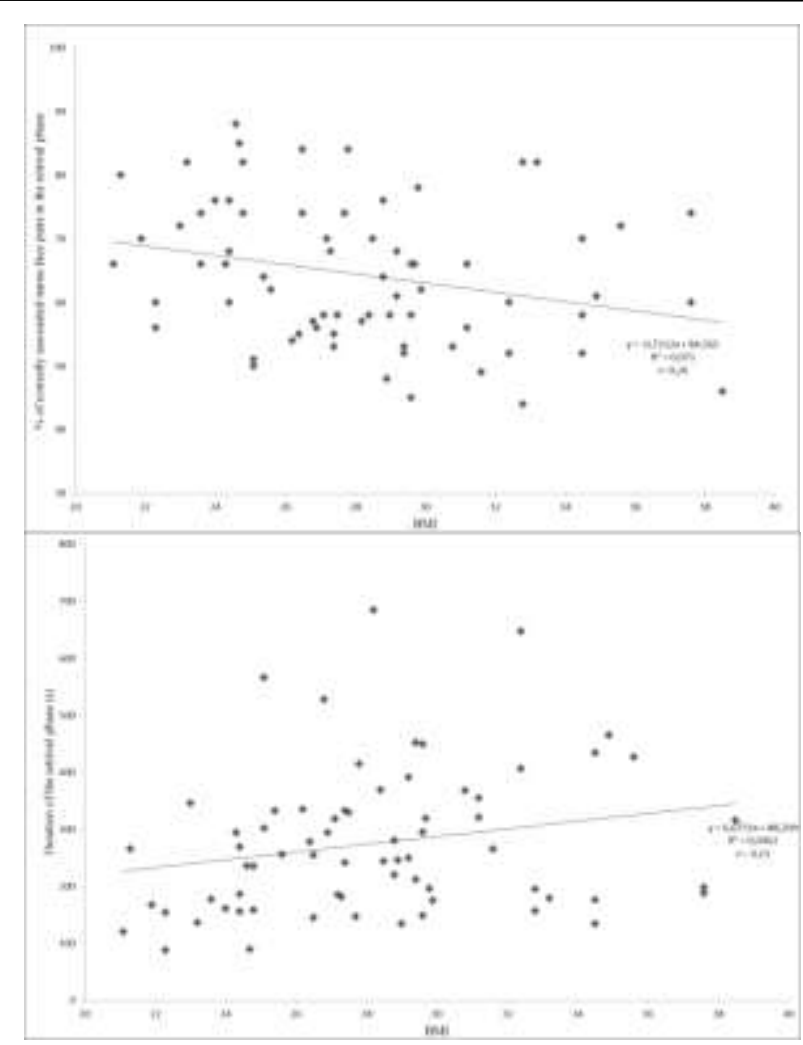

Fig. 2. Correlation between BMI and the face/name association test results in overweight and obese group. The \% of correctly associated name-face pairs in the retrieval phase (a) or the duration of the retrieval phase (b) is plotted against individual BMI values

Ryc. 2. Zależność pomiędzy BMI $i$ wyniki testu kojarzenia twarz/imię $w$ grupie osób z nadwaga oraz $w$ grupie osób otytych. \% twarzy poprawnie skojarzonych $z$ imieniem $w$ fazie odtwarzania a) średnie wartości uzyskane w poszczególnych; $p<0,05$ b) Czas trwania fazy odtwarzania; $p<0,05$

Interestingly, we did not observe any significant progression of cognitive impairment between overweight and obese groups of subjects. This observation suggests that the observed correlation between the body mass and performance in our cognitive test may be a threshold phenomenon. Even the low levels of excessive body weight may result in significant cognitive decline without significant additional decline associated with further increase in body weight.

The relationship between body weight and cognitive function is not yet completely understood. The observed differences in cognitive test performance between normal, overweight and obese group indicated the potential impact body mass has on cognitive function (declarative memory). The impact of body mass weight on the face/name association test result seems to be independent of age [8]. Moreover, the volunteers were healthy and therefore, we can exclude 
impact co-existing illnesses such as hypertension or diabetes on cognitive function $[9,30]$.

Our findings are concordant with the results from other studies which demonstrated lower levels of cognitive performance such as executive function $[7,8,23]$ or attention and memory $[10,31]$ in overweight and obese people. In animal models, it was also found that the cognitive parameters are influenced by obesity. In high-fat feeding models of obesity, impairments of working memory [32], learning [20], and memory performance [33,34] have been observed. However, other studies demonstrated that increased body-weight has no effect on cognitive performance $[35,36]$. For example, in one study overweight subject scored higher on reasoning task and visual-spatial tests than normal weight subjects [37]. Different effect of body weight on cognitive ability may be associated with other factors such as hypertension, gender, hormone levels and topological distribution of body fat, lifestyle and diet $[30,38]$

Our results are consistent with findings reported by other labs. The data strongly suggest a link between body mass and the level of cognitive performance $[7,8,23]$. Namely, excessive body mass appears to be an important factor in the development of cognitive dysfunction.

\section{REFERENCES}

1. Kopelman PG. Obesity as a medical problem. Nature 2000; 404: 635-643.

2. Hart DJ, Spector TD. The relationship of obesity, fat distribution and osteoarthritis in women in the general population: the Chingford Study. J Reumatol 1993; 20: 331-5.

1. Haslam DW, James WP. Obesity. Lancet 2005;366:11971209.

2. Hannestad YS, Rortveit D, Deltveit AK et al. Are smoking and other lifestyle factors associated with female urinary incontinence? BJOG 2003;110:247-254.

3. Jensen GL, Friedmann JM. Obesity is associated with functional decline in community-dwelling rural older persons. J Am Geriatr Soc 2002; 50:918-923.

4. Bergstrom A, Pisani P, Tenet V et al. Overweight as an avoidable cause of cancer in Europe. Int J Cancer 2001; 91: 421-30.

5. Boeka AG, Lokken KL. Neuropsychological performance of a clinic sample of extremely obese inviduals. Arch Clin Neuropsychol 2008; 23:467-474.

6. Gunstad J, Paul RH,Cohen RA et al. Elevated body mass index is associated with executive dysfunction in otherwise healthy adults. Compr Psychiatry 2007; 48: 57-61.
7. Elias MF, Elias PK, Sullivan LM et al. Lover cognitive function in the presence of obesity and hypertension. Int J Obes Relat Metab Disord 2003;27:260-268.

8. 10.Cournot M, Marquie JC, Ansiau D et al. Relation between body mass index and cognitive function in healthy middle-aged men and women . Neurology 2006; 67:1208-1214.

9. 11.Sabia S, Kivimaki M, Shipley MJ et al. Body mass index over the adult life course and cognition in late midlife: the Whitehall II Cohort Study. AM J Clin Nutr 2009;89:601-607.

10. 12.Stanek KM, Strain G, Devlin M et al. Body mass index and neurocognitive functioning across the adult lifespan. Neuropsychology 2013;27:141-151.

11. Whitmer RA, Gunderson EP, Barrett-Connor E. Obesity in middle age and future risk of dementia. A 27 year longitudinal population based study. BMJ 2005; 3301360

12. Gustafson.D, Rothenberg E, Blennow K et al. An 18-year follow-up of body mass index and risk for Alzhaimer's disease. Arch Intern Med 2003; 163:1524-1528.

13. Gustafson D. Adiposity indices and dementia. Lancet Neurol 2006; 5:713-720.

14. Enzinger C, Fazekas F, Matthews PM et al. Risk factors for progression of brain atrophyin aging: six-year followup of normal subject. Neurology2005;64:1704-1711.

15. Ward MA, Carlsson CM, Trivedi MA et al. The effect of body mass index on global brain volume in middle-aged adults. A cross sectional study. BMC Neurol 2005; 5:23.

16. Taki Y, Kinomura S, Sato K et al. Relationship between body mass index and gray metter volume in 1,428 health inviduals. Obesity 2008; 16: 119-124.

17. Gustafson D, Lissner L, Bengtsson C et al. A 24-year follow-up of body mass index and cerebral atrophy. Neurology 2004;63: 1876-1881.

18. Molteni R, Barnard RJ, Ying Z et al. A high-fat refined sugar diet reduces hippocampal brain-derived neurotrophic factor, neuronal plasticity and learning. Neuroscience 2002;112:803-804.

19. Wu A, Molteni R, Ying $\mathrm{Z}$ et al. A saturated-fat diet aggravates the outcome of traumatic brain injury on hippocampal plasticity and cognitive function by reducing brain derived neurotrophic factor. Neuroscience 2003;119:365-375.

20. Moraes JC, Coope A, Morari J et al. High-fat diet induces apoptosis of hypothalamic neurons. PloS One 2009;4:5045-5056.

21. Volkov ND, Wang GJ, Telang $F$ et al. Inverse association between BMI and prefrontal metabolic activity in healthy adults. Obesity 2009; 17:60-65.

22. Harvey J. Leptin regulation of neuronal excitability and cognitive function. Curr Opin Pharmacol 2007; 7:643647.

23. Gunstand J, Spitznagel MB, Keary TA et al. Serum leptin levels are associated with cognitive function in older adults. Brain Res 2008;1230:233-236.

24. Sriram K, Benkovic SA, Miller DB et al. Obesity exacerbates chemically induced neurodegeneration. Neuroscience 2002;115:1335-1346. 
25. Gorelick PB. Role of inflammation in cognitive impairment: result of observational epidemiological studies and clinical trials. Ann NY Acad Sci2010;1207:155-1562.

26. Obesity Education Initiative: The Evidence Report. Bethesda, MD: National Heart Lung and Blood Institute, National Institutes of Health, 1998.

27. Złomańczuk P, Milczarek B, Dmitruk $\mathrm{K}$ et al. Improvement in the face/name association performance after three months of physical training in elderly women. J Physiol Pharmacol 2006;57: 417-424.

28. Elias MF, Elias PK, Sullivan LM et al. Obesity, diabetes and cognitive deficit: the Framingham Heart Study. Neurobiol 2005;26:11-16.

29. Gunstad J, Paul RH, Cohen RA et al. Obesity is associated with memory deficits in young and middleaged adults. Fat Weight Disord 2006;11:9-15.

30. Jurdak N, Lichtenstein AH, Kanarek RB. Diet-induced obesity and spatial cognition in young male rats. Nutr Neurosci 2008;11:48-54.

31. Granholm AC, Bimonte-Nelson HA, Moore AB et al. Effects of a saturated fat and high cholesterol diet on memory and hippocampal morphology in the middleaged rat. J Alzheimers Dis 2008;14:133-145.

32. Kanoski SE, Davidson TL. Different patterns of memory impairments accompany short and longer -term maintenance on a high - energy diet. J Exp Psychol Anim Behav Process 2010;36:313-319.
33. Sweat V, Starr V, Bruehl H et al. C-reactive protein is linked to lower cognitive performance in overweight and obese women. Inflammation 2008;31:198-207.

34. Ward MA, Carlsson CM, Trivedi MA et al. The effect of body mass index on global brain volume in middle-aged adults: a cross sectional study. BMC Neurol 2005;2:5-23.

35. Kuo HK, Jones RN, Milberg WP et al. Cognitive function in normal-weight, overweight and obese older adults: an analysis of the Advanced Cognitive Training for Independent and Vital Elderly cohort. J Am Geriatr 2006;54:97-103.

36. Goodman-Gruen D, Barrett-Connor E. Sex differences in body fat and body fat distribution in the elderly .Am $\mathrm{J}$ Epidemiol 1996;143:898-906.

Address for correspondence:

Blanka Dwojaczny

Katedra Fizjologii Człowieka

85-092 Bydgoszcz

Karłowicza 24

e-mail: blanka.dwojaczny@cm.umk.pl

tel: (52) 5853719

Received: 26.04.2016

Accepted for publication: 28.06.2016 